\title{
Socio-economic problems in a mining town during the economy restructuring period on the example of Ruda Śląska, Poland
}

\author{
Kinga Mazurek \\ Department of Physical Geography, Faculty of Earth Sciences, University of Silesia, Będzińska 60, 41-200 Sosnowiec, Poland \\ E-mail address: mazurek.kingaa@gmail.com
}

\begin{abstract}
The 90s of the twientieth century carried a restructuring of the industry which involved the adaptation of enterprises to operate in a market economy, the workforce reduction and privatization of industrial facilities. Economic transformation has contributed to the socio-economic changes in industrial and mining towns. It affected the changes in the employment structure, changes in the number of population, migration decisions, the quality of medical care and municipal institutions support. Ruda Śląska is a typical mining town, history of which for nearly 200 years has been a consecutive period associated with the mining and heavy industries. This work is based on statistical data and approximates the effects of restructuring evident in Ruda Śląska. The presented characterization indicates that the situation prevailing in the city refers to the conditions of life in the most traditional mining regions of Central and Eastern Europe. Despite the significant reconstruction in the employment structure, Ruda Śląska retains partly its mining character. Population of the town is trying to cope with the need to adapt to new economic realities, among others, by changing the sector of economy to work in. Employment reductions have contributed to the increase of population migration. In conjunction with the natural loss it resulted in a decrease of the number of population and population aging. The support of the cities and sanitary facilities offered, among others, by social assistance centers and employment has great importance in overcoming the negative effects of the economic transformation.
\end{abstract}

KEY WORDS: coal mining, restructuring, unemployment, migration, Katowice conurbation

\section{Introduction}

The fall of communism and the change of the political system in Poland have significantly influenced the state of the national economy. In 1989 an industrial restructuring involving the adjustment of enterprises to operate in a market economy was introduced. The transformation consisted in the conversion of the ownership structure and privatization of state enterprises. Industry restructuring was carried out throughout the country, but it was the most important for the contemporary voivodeship of Katowice (now Silesian voivodeship), which then played a major role in the Polish industrial production. In the conditions of socialist economy the production in mining and heavy industries, which was dominant in the region, was material consuming and capitalintensive. The changes introduced resulted, among others, in a decline in production and a decrease in the percentage share in the production of gross domestic product, while the importance of market services has increased.

The restructuring of traditional industries in Silesian region - coal mining, resulted in a decrease in demand for coal, overproduction of raw materials and unprofitable mines, and consequently the liquidation of many factories and reduction of jobs. The main objectives of the mining restructuring program was adaptation to production possibilities, reduction of employment (not accepting new employees, transferring miners from closed mines to other plants) and the privatization of individual complexes and branches. In the years 1989-2003 twenty-nine mines were closed and employment in Polish mines decreased by 280 thousand people - from 415740 in 1989 to 135704 in 2003 (TKOCZ, 2006a). The reduction in employment 
was associated with the need to introduce a system of social protection. The second phase of the restructuring of coal mining, which was implemented between 1994 and 1995, assumed the state budget to cover the technical costs of mine closure and payment for social protection for miners who voluntarily choose to leave the mining industry. Economic subsidy for this purpose was to reach nearly 2.7 billion PLN. In addition, the program was to provide new jobs to all the miners who would be dismissed from the liquidated mines. The implementation of government programs (RESTRUKTURYZACJA GÓRNICTWA, 1993; GÓRNICTWO WĘGLA KAMIENNEGO, 1996; REFORMA GÓRNICTWA, 1998; PROGRAM LIKWIDACJI, 1999; RESTRUKTURYZACJA GÓRNICTWA, 2004) did not, however, fully satisfy the needs of the miners and did not solve social problems that have generated in areas related to closed plants. A problem of unemployment and the difficulty of career re-activation occurred among the redundant miners. Consequently, the lack of jobs and deteriorating economic conditions revealed poverty and social pathologies. These problems occurred especially in the cities, which during the socialist economy developed on the basis of operating in these areas coal mines, for example, in Katowice, Zabrze, Knurów, Łaziska Górne, or Bytom.

This paper presents the socio-economic changes caused by industrial restructuring in one of the most typical mining towns in the Upper Silesian Coal Basin - Ruda Śląska. The development of this city was associated with the mining and heavy industries for two centuries. Coal mining ensured not only jobs for residents, but also influenced the spatial development of the city, the population's direction of education, or the state of the natural environment. The restriction of mining activities, initiated in the 90 s of the twentieth century, has generated a number of social problems. Unemployment had appeared, and the general deterioration of living conditions came along with it. Ruda Śląska faced the need to change the direction of development in order to provide existence for its residents.

\section{Source materials and research methods}

The analysis was conducted on the basis of the Central Statistical Office data for the period from 1990 to 2012, as well as the materials developed at the request of various institutions operating in the city. "Urban social problem-solving strategy for the years 2003 -2015", containing a diagnosis of social problems in Ruda Śląska in the early 2000s, was used above all (CZĘŚĆ OGÓLNA MIEJSKIEJ STRATEGII, 2004), and it was based on the data from institutions such as District Employment Office, Police and Municipal Police, the District Court, the Board of Detention, or Alcohol Addiction Treatment Clinic. An important source of data was the "Local development plan of Ruda Śląska for 2004-2013" (Plan Rozwoju LOKALnEGO, 2004). The analysis of socio-economic problems was carried out in relation to particular districts, focusing on a few selected issues: unemployment, demographic structure, migrations, housing conditions, alcoholism, and care and education helplessness.

\section{Field of the study}

Ruda Śląska is a city located in the center of Silesian region. It also belongs to the Katowice conurbation. The town was created by a combination of a number of small rural and urban districts. Currently, the area of Ruda Śląska comes to $78 \mathrm{~km}^{2}$ and today's approximate range was gained by the town in 1959. Ruda Śląska does not have a strictly designated center. There are only functional centers distinguished: administrative New Bytom and trade - Wirek district. At the date of 31.12.2012 the number of population amounted to 142.3 thousand people and the population density - less than 1830 people $/ \mathrm{km}^{2}$ (www.stat.gov.pl). About half of the city's population lives in three districts - Halemba (about 26 thousand), Ruda (about 23 thousand), and Wirek (about 19 thousand) (LOKALNA STRATEGIA ZATRUDNIENIA, 2008). Fig. 1 shows the population density in individual districts of Ruda Śląska. The town is crossed by two highways - the southern districts by the A4 highway, while the northern districts - DTŚ.

Ruda Śląska is located in the Silesian Upland (KONDRACKI, 2002) at an altitude of $225-320 \mathrm{~m}$ above sea level. The lie of the land is dominated by flattened hilltops, built from the Upper Carboniferous rocks (sandstones and argillaceous rocks with coal seams). In the valleys and on the slopes occur Pleistocene and Holocene clayey and sandy sediments (SZCZEGóŁOWA MAPA GEOLOGICZNA, 1960). The city area is strongly transformed as a result of mining and industrial activities and urbanization. In the landscape there are numerous anthropogenic landforms - dumping grounds, subsidence basins, excavations after opencast exploitation of raw materials, embankments and communication pits. 


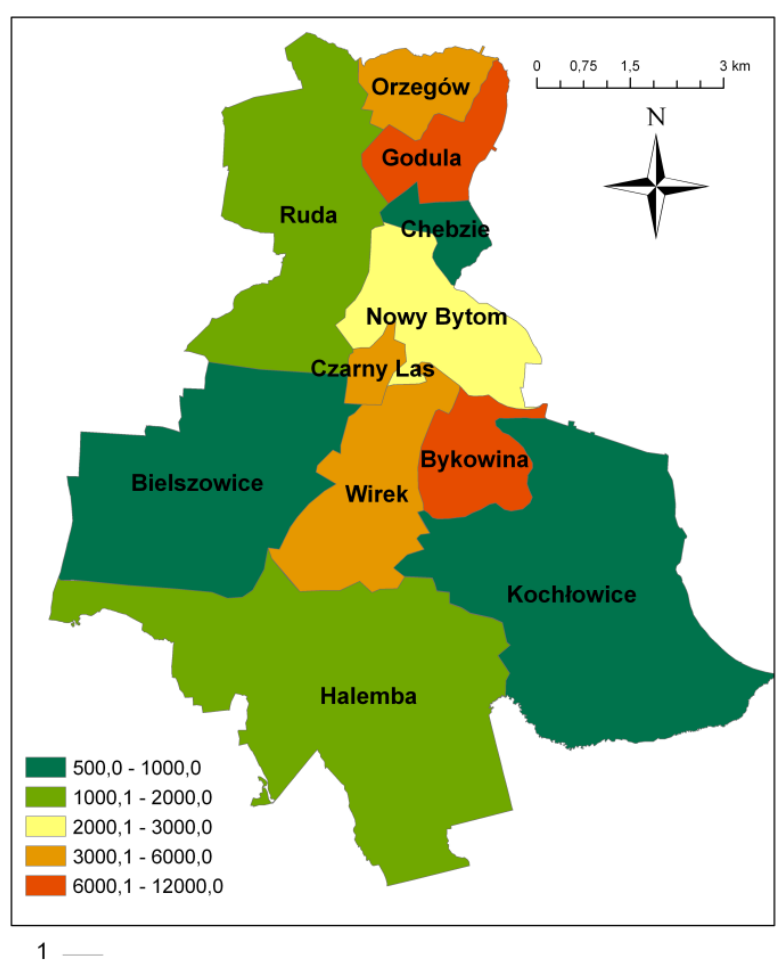

Fig. 1. Population density in Ruda Śląska districts in 2005 (after Lokalna strategia zatrudnienia, 2008)

\section{Outline of the socio-economic development of Ruda Śląska}

The city of Ruda Śląska came into existence in the result of merging small forging settlements deposited under German law. The main occupation of the population was agriculture and primitive ferrous metallurgy. Coal was discovered in the seventeenth century, and its proper exploitation began in the eighteenth century (DWORAK, 1970). The oldest mine in the city is considered to be the "Brandenburg" mine, which existed already in 1752. Many small mines were active, in the initial period of mining development in the city, that coal mined in a primitive way, mainly on outcrops seams. In addition to the coal mines in Ruda Śląska, numerous zinc smelters and ironworks, as well as coking plants and brickyards were created. At the end of the nineteenth century mines merged into bigger and bigger plants thanks to the concentration of production it was possible to increase the depth of exploitation, make better use of resources, and above all to increase extraction. In the second half of the nineteenth century within the city at least 41 million tons of coal was extracted (LUKSA, 1959; MAZUREK, in print). Coal export was enabled by the railway line Berlin - Mysłowice built during this period, which ran through Ruda Śląska (JAROS, 1970). In connection with the development of the industry large groups of people came to the city - in the period 1855-1910 the number of population increased from less than 11 thousand to 87 thousand.

In the first half of the twentieth century, coal mining developed in Ruda Śląska very intensively. In the years 1900-1945 in all mines in the city 215 million tons of coal was extracted, which is five times more than in the previous fifty years. The most important mines were "Wawel" (Fig. 2), "Wanda", "Walenty", "Wirek" and "Pawel". On the eve of World War II Ruda Śląska was, hence, already an important mining center on the map of the Upper Silesian Coal Basin. In 1936, the city was inhabited by 118.5 thousand people.

Strong demand for coal by the rebuilding economy after World War II was an impetus for the development of mining in the city - three new mines were built here - "New Wirek", "Halemba" and "Silesia". In the postwar period, until the restructuring of the economy, within the limits of Ruda Śląska at least 430 million tons of coal was extracted. With the development of industry the number of population increased - in 1967 amounted to almost 142 thousand, and in the early 90s of the twentieth century has exceeded 160 thousand people. In connection with such a large increase in the number of residents in the city there were built new housing estates, numerous schools (including vocational schools educating to work in the mining industry), health centers and various public facilities. The mining activity in the city was clearly limited as a result of industrial restructuring. Currently there are four mining plants operating here.

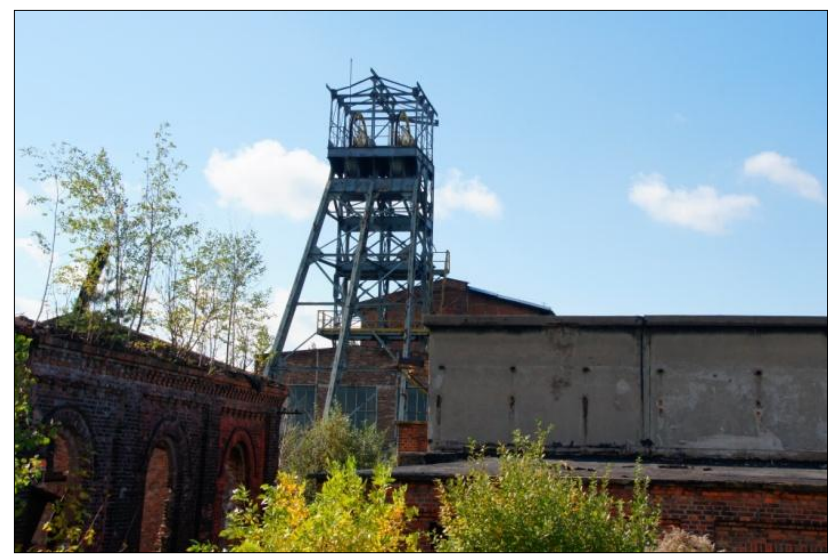

Fig. 2. "Klara" shaft in abandoned mine "Wawel" (K. Mazurek)

\section{Socio-economic problems of Ruda Śląska during the restructuring period}

Social welfare, or social situation of the population living in industrialized areas, is characterized on the basis of the residents' health, unemployment, housing needs, the areas 
of poverty and social assistance (MAGDA-ŻABIŃSKA, 2008). The social situation in Ruda Śląska is largely associated with mining activities in this area. Coal mines employed not only city residents but also provided appropriate social and living conditions. The miners could count on the company apartments, access to health care, pay supplements, food stamps and ability to send children to summer camp organized by the establishment. Currently, due to the reduction of mines and jobs, the situation of the residents has changed.

\subsection{Effects of restructuring on the labor market}

There are four deep mines operating in Ruda Śląska (Fig. 3). Longwall mining with caving method and partly with the use of hydraulic backfill is conducted there. The mines "Pokój" "Bielszowice" and "Halemba-Wirek" belong to Kompania Weglowa, and the mine "Śląsk" belongs to KHW (http://gornictwo.wnp.pl/kopalnie/).

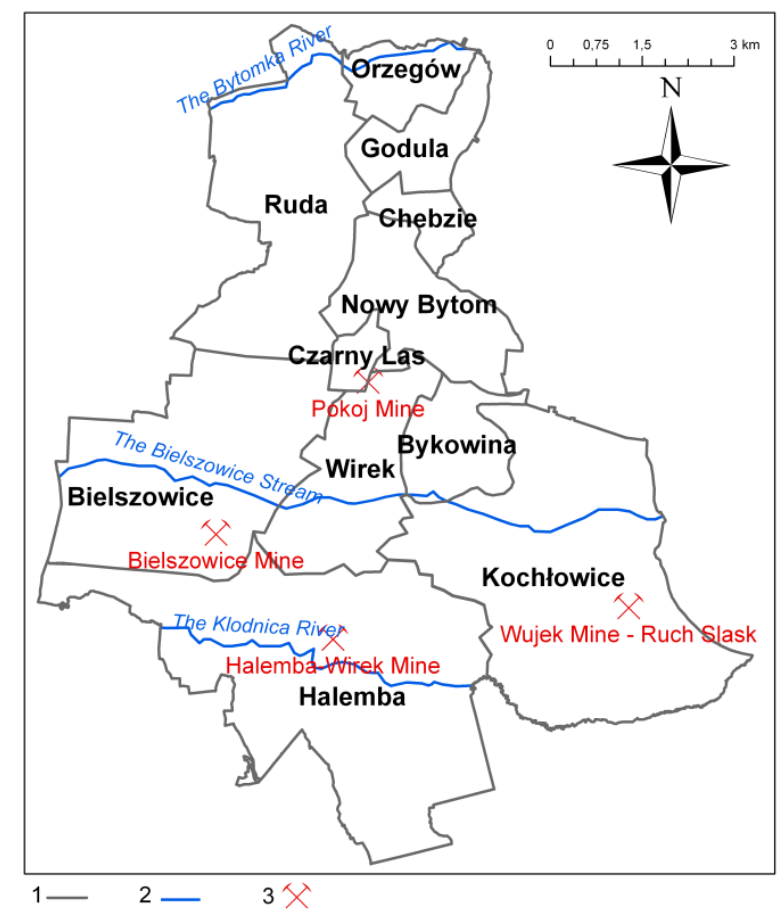

Fig. 3. Coal mines in Ruda Śląska (at the date 01.01.2013) 1 - administrative division; 2 - river; 3 - mine

Mine "Pokój" operates the districts of Wirek, New Bytom, Bielszowice, Czarny Las. These are highly urbanized districts of Ruda Śląska. The daily extraction stands at 5500 tons of coal. The plant employs approximately 2099 employees, including 1,569 employees working underground. Mine "Bielszowice" covers an area of $34.1 \mathrm{~km}^{2}$ and is located in three cities: Zabrze, Ruda Śląska and Mikołów. The production capacity of the plant on the exploitation front is estimated at 8500 tons per day. Mine "Bielszowice" employs an average of 3660 people, 2964 of whom are working underground. Mine "Halemba-Wirek", located in Halemba district, is a two-level mine. Since 2007, it is a two-way plant. The mining area covers $56.22 \mathrm{~km}^{2}$. Average employment amounts to 3815 employees, including 3027 employees working underground (www.kwsa.pl/). Previous mine "Śląsk" is currently working (since 2005) as the mine "Wujek" Movement (Mine "Wujek" Movement Śląsk). The branch is located in the district of Kochłowice (www.khw.pl/).

Mining is still a major industry branch in the city. In spite of the conducted restructuring, mines still continue to employ the largest number of people. Coal mining creates jobs not only in mining plants and power plants singed with this raw material, but also in companies which are technical, scientific, and in services. In addition, there is a metal processing industry and the construction industry operating in the city. There are a total of 18649 people employed in the second sector of the economy (industry). Far more men (15 766 persons) than women (2 883 people) are working in the industry. This represents $53.0 \%$ of the total working population of Ruda Śląska (as of 31.12.2012, www.stat.gov.pl).

The service sector is a sector that continues to grow from year to year more and employ more workers, among other things, such services include: trade, repair of motor vehicles, transport, logistics, warehousing, financial and insurance activities, real estate activities, gastronomy, information and communication, and other services. 16266 people are employed altogether in the third sector of the economy. Among the employed dominate women (10 357) over men (5 909). Employees of the service sector represent $46.3 \%$ of the total working population (as of 31.12.2012, www.stat.gov.pl).

Despite the typically industrial and commercial character of the city of Ruda Śląska several farms with animal husbandry and cultivation of land survived. In 2012, this sector of the economy (agriculture, forestry, hunting and fishing) employed 247 people, including 162 men and 85 women. This represents $0.7 \%$ of the working population of the city. Detailed data on employment are summarized in Table 1.

In the employment structure very clear changes occurred. Employment in the second sector of the economy within 17 years decreased by 16407 people. It is associated with the restructuring of the mining and heavy industries. In addition, there was an increase in employment in the services sector (an increase in employment of 14306 people in 1995 to 16266 people in 2012), which 
is associated with the progressive development of this sector. the cross-industry is dominated by wholesale and retail trade, repair of motor vehicles and household appliances. Based on the structure of employment, the type of city according to the nature of the functional dominance can be specified. In the late 70s Ruda Śląska was designated as a city of industry and mining. In the 80s and 90 s of the twentieth century the town was a center of mining and service. In 2003, the city acquired the nature of service and mining (TKOCZ, 2006b). There was also an increase in the number of people working in agriculture, forestry and hunting (an increase in employment of 183 people in 17 years).

In 2012, the number of employed residents of the city amounted at 35162 people. There have been 4242 unemployed noted. The share of the unemployed in the total working age population in 2012 was $4.6 \%$, while the unemployment rate was about 9.0\% (as at 31.12.2012, www.stat.gov.pl). It should be highlighted that in 2000 there were as many as 7290 registered unemployed people (the unemployment rate was $12.1 \%$ ). The number of registered unemployed in the city reduces significantly. This trend, remaining on the urban labor market, can be interpreted in two different ways. It may reflect both the actual decline in the unemployment rate, or, more likely, the fact that the unemployed do not register with the employment office. A dose of restraint should then be retained when reading this indicator. In terms of the share of total employment in the total population Ruda Śląska is ranked 6th among the Katowice conurbation cities (LOKALNA STRATEGIA ZATRUDNIENIA, 2008).

Table 1. Employment by sectors of the economy (by Rocznik statystyczny, 1995; www.stat.gov.pl/gus, 1995-2012)

\begin{tabular}{|c|c|c|c|c|c|}
\hline Year & $\begin{array}{c}\text { Industry and } \\
\text { construction }\end{array}$ & $\begin{array}{c}\text { Services } \\
\text { (overall) }\end{array}$ & $\begin{array}{c}\text { Agriculture, forestry, } \\
\text { hunting and fishing }\end{array}$ & In total & $\begin{array}{c}\text { Number of registered } \\
\text { unemployed }\end{array}$ \\
\hline 1995 & 35056 & 14306 & 64 & 49426 & 6339 \\
\hline 2000 & 28195 & 13250 & 93 & 41538 & 7290 \\
\hline 2005 & 21928 & 14991 & 121 & 37040 & 6611 \\
\hline 2010 & 19384 & 14807 & 226 & 34417 & 3923 \\
\hline 2012 & 18649 & 16266 & 247 & 35162 & 4242 \\
\hline
\end{tabular}

Industrial restructuring and closing of mines deepened the problem of unemployment among redundant miners. There was also the issue of retraining and professional activation. The reaction of the city's population to economic changes is the formation of a large number of small and mediumsized businesses. The dynamic development of private sector companies is visible primarily in the service industries, trade and transport. The service sector is currently the most thriving generator of job positions. What is more, unemployment among young people (less than 30 years old) plays a great part. University graduates are also facing the problem of finding a job (in 2012 - 409, while in 2000 - 726 registered unemployed). The most numerous groups of the unemployed are those who completed only high school or elementary school (1 387 people) and vocational schools (1 244 people). The graduates of secondary schools and secondary vocational schools are in a better situation (subsequently 350 and 852 people) (as at 31.12.2012, www.stat.gov.pl).

It is estimated that the average monthly gross salary is nearly 3309.17 PLN. Compared to 2005, the value of the average monthly gross salary increased significantly by 1 162.65 PLN (as for
31.12.2012, www.stat.gov.pl). Average monthly gross salary which has been calculated for the inhabitants of Ruda Śląska is $88.4 \%$ in relation to the national average. It should be noted that the benefits given are disproportionately high for the actual salary of an average citizen. Very high earnings produced by the members of the boards and companies' management as well as private, successful companies are pushing up the value of the average wage of the average inhabitant.

\subsection{Changes in population number of the city}

Socio-economic situation of areas redeveloped and restructured also significantly reflect migrations. In 2012, 1535 people emigrated beyond the boundaries of Ruda Śląska. Fewer people immigrated to the city, ie. 985. Migration balance was then 550. Turnover migration amounted to 2520 people in 2011 (as for 31.12.2012, www.stat.gov.pl). In 1995, the migration balance was 366. During that year, the city attracted 1217 people and 1583 of Ruda Śląska inhabitants decided to leave the city. Both the number of emigrants and immigrants decreased; however, a large turnover migration is seen. Residents of the 
city decide to leave the towns if they have the opportunity to improve their economic and housing situation. Migrations are therefore primarily conditioned a commercial factor. The most common decision made is to migrate abroad. Also in this case, such a tendency is observed in the whole province. A significant decrease in the rate of leaving the city in recent years should be noted. This is a positive aspect of the population state of Ruda Śląska.

Changes connected with transformation and restructuring had an impact on various aspects of life, including the general number of population, the age groups economic structure or in natural movement of inhabitants. In the structure of the population by economical age group, first place goes to the economically productive age (18-59 year-old women, 18-64 year-old men) which is 92133 people, including 48367 men and 43766 women, representing $64.7 \%$ of the population. The next place comes to the beyond retirement age population (25 213 people) and a group of pre-working age (25 000 people). In 1995, the size of economic age groups presented as follows: a group of pre-working age population consisted of 43719 people, a group of working-age population consisted of 103711 people, and the beyond retirement age group consisted of 18443 people. Within 17 years there have been significant changes in the number of these groups. The number of pre-working age group decreased by
18719 people. The working age group also decreased (by 11578 people). In the oldest age group, however, there was a significant increase in the number of people, which was as high as 6770 . This clearly indicates the process of aging. The aging of society is contemporary commonly occurring phenomenon. It is associated with low birth rate (or loss) and negative migration balance. Currently, in terms of population, the city is classified on the 8th position in the Silesian province, and on the 24 th position in the country. The forecasts prepared for the years 2020 and 2030 estimate that the number of inhabitants of the town Ruda Śląska will be systematically reduced to successively reach levels 135762 and 127054 people (as of 31.12.2012, www.stat.gov.pl).

In 2012, there were 1497 live births and 1,608 deaths recorded in the city. In comparison to 1995 the number of births decreased. Reducing the number of births in the city refers to the trend that has been taking place across the country. The decision of having a baby is taken less frequently than at one time, and the women decide to have children much later. The number of deaths has also significantly reduced. This fact, in turn, proves the lengthening of average life expectancy, and, possibly, access to better medical care. In terms of Ruda Śląska it should be said about the loss, which is 111. Detailed information on the number of births and deaths are given in Table 2.

Table 2. Natural movement in Ruda Śląska (by Rocznik statystyczny, 1995; www.stat.gov.pl/gus, 1995-2012)

\begin{tabular}{|c|c|c|c|c|c|c|}
\hline \multirow{2}{*}{ Years } & \multirow{2}{*}{ Life births } & \multirow{2}{*}{$\begin{array}{c}\text { Deaths } \\
\text { altogether }\end{array}$} & \multirow{2}{*}{$\begin{array}{c}\text { Infant } \\
\text { deaths }\end{array}$} & $\begin{array}{c}\text { Cardiovascular diseases } \\
\text { altogether [\%] }\end{array}$ & $\begin{array}{c}\text { Tumours } \\
\text { altogether [\%] }\end{array}$ & Natural loss \\
\cline { 5 - 6 } & & 1644 & 26 & - & - & -105 \\
\hline 2000 & 1403 & 1582 & 17 & 47.9 & 21.5 & -179 \\
\hline 2005 & 1329 & 1579 & 4 & 46.5 & 25.1 & -250 \\
\hline 2010 & 1561 & 1600 & 11 & 41.1 & 26.4 & -39 \\
\hline 2011 & 1449 & 1567 & 7 & 39.1 & 28.0 & -118 \\
\hline 2012 & 1497 & 1608 & 12 & 39.9 & 28.0 & -111 \\
\hline
\end{tabular}

\subsection{Health status of the residents and medical care}

The main causes of death of the city residents are: cardiovascular diseases, cancers and external causes of death. There has been a reduction in mortality caused by cardiovascular diseases (Table 2). There is a high level of deaths caused by injury and external issues in Ruda Śląska.

Currently, the city has two public city hospitals, with 474 beds for patients, and 51 clinics (including 11 public and 40 which are nonpublic). The number of doctors in the city (according to the basic job) is 214, and the number of dentists is 30 (as for 31.12.2011, www.stat.gov.pl). In 2001, an average of 565 people fell to one doctor (which the 21st place has given among the districts of the voivodeship), an average of 3605 people fell to one dentist (11th position), and to one nurse - 241 people (19th position) (CZĘś́ Ogólna MiejSKIEJ STRATEgiI, 2004). In comparison 
with 1995 the state of health care staff remained mostly unchanged: an average of 574 people per one doctor, an average of 3966 people per dentist, and 215 people per one nurse (RoczNIK STATYSTYCZNY, 1995).

\subsection{Social problems and support of municipal institutions}

For a full picture of the socio-economic situation of city residents it is necessary to approximate the diagnosis of social problems. These information come mainly from Social Welfare Centre studies. The most statistically significant social problems include: unemployment, alcohol problem, helplessness in matters of parental care, especially in single-parent families and families with many children, as well as disability.

The phenomenon of scarcity and poverty in the area of Ruda Śląska is associated with abandonment of industrial sources of income and restructuring. Crisis and problematic situations apply to people who have lost their previous employment, and young people with primary or, at most, vocational education which are often single or unmarried. Unemployment is a dysfunction of the greatest abundance and a high growth rate. Neighborhoods where unemployment is noted the most often are: Ruda (21.7\% of all backgrounds applying for unemployment assistance) as well as Chebzie and Nowy Bytom $(23.2 \%$ altogether $)$ (Plan RozWoju Lokalnego Miasta, 2004). Difficult living situation, material problems and long-term unemployment often result in addiction to alcohol or mental disorders. Highest severity of alcoholism is recorded in the following neighborhoods: Wirek $(26.1 \%$ of all backgrounds applying for alcoholism aid) as well as Chebzie and Nowy Bytom (22.4\% altogether). In 2011 there were 174920 people registered (including 24,847 people with disorders due to alcohol use) in Ruda Śląska clinics for people with mental disorders and those with alcohol dependence. Helplessness in matters of parental care and household maintenance is recorded primarily in Godula $20.5 \%$ of all backgrounds applying for aid due to helplessness), Orzegów (17.5\%) and Ruda (12.8\%). However, the disability social assistance benefits primarily went to Halemba residents $(17.9 \%$ of all backgrounds applying for aid from disability) as well as Chebzie and Nowy Bytom (14.6\% altogether) (PLAN ROZWOJU LOKALNEGO MIASTA, 2004). Figures 4-6 presents the phenomenon of social dysfunction in selected districts.

Based on the above data, it can be concluded that the location of hazards that could affect the proper functioning of families dominate the northern and central districts of the city. However, based on the City Strategy for Solving Social Problems Years 2003-2015, the areas of the city which disorganize social life may be shown (CZĘŚĆ OGÓLNA MIEJSKIEJ STRATEGII, 2004). The main indicators of environmental concentration in the problematic situation and crisis are the streets. In 2001, nearly $15.3 \%$ of all people in a problematic situation and crisis moved in to 10 streets (out of 603). These are the following streets: 1 Maja (Halemba, Wirek, Czarny Las, Nowy Bytom, Ruda districts) - 3.0\%, Niedurnego (Nowy Bytom district) $2.9 \%$, Norwida (Ruda district) - 1.4\%, Podlas (Orzegów district) - 1.4\%, Piastowska (Ruda district) - 1.2\%, Katowicka (Wirek district) - 1.2\%, Westerplatte (Wirek district) - 1.1\%, Wolności (Ruda district) - 1.1\%, Miedzyblokowa (Halemba district) 1.0\%, Energetyków (Halemba district) - 1.0\% (CZĘŚĆ OGóLNA MIEJSKIEJ STRATEGII, 2004).

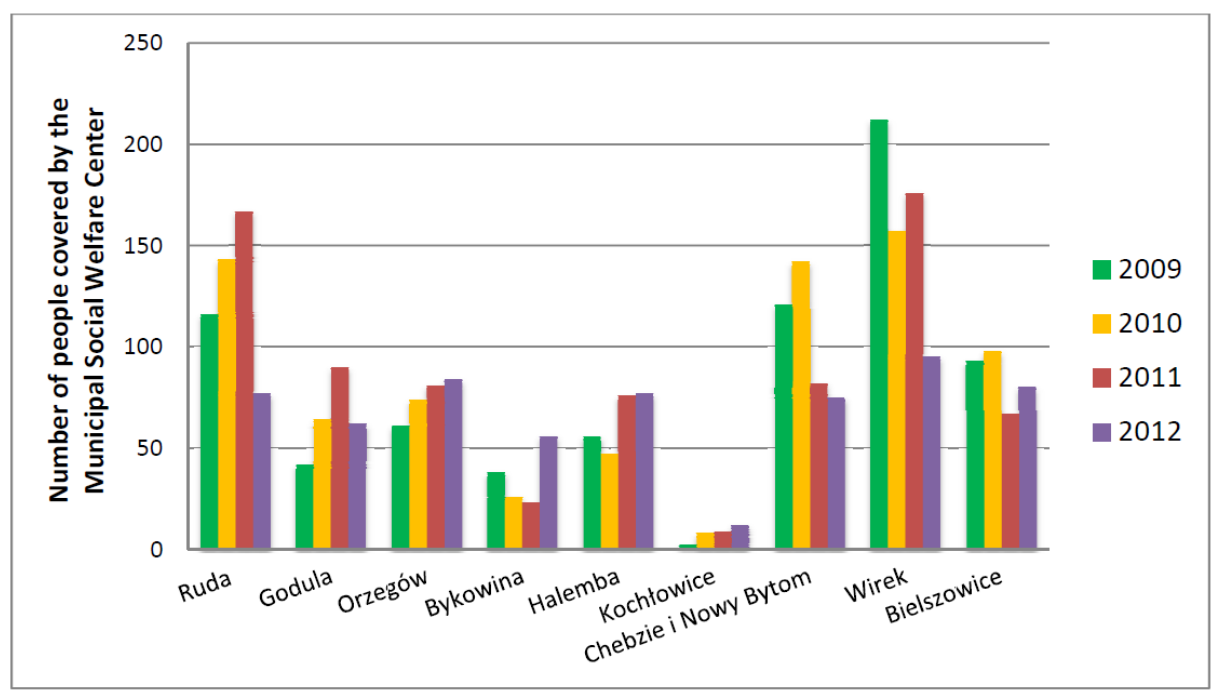

Fig. 4. Number of persons covered by the Social Welfare Centre (MOPS) for alcoholism in different districts of Ruda Śląska (own study, by www.mops.rsl.pl/monitor.html) 


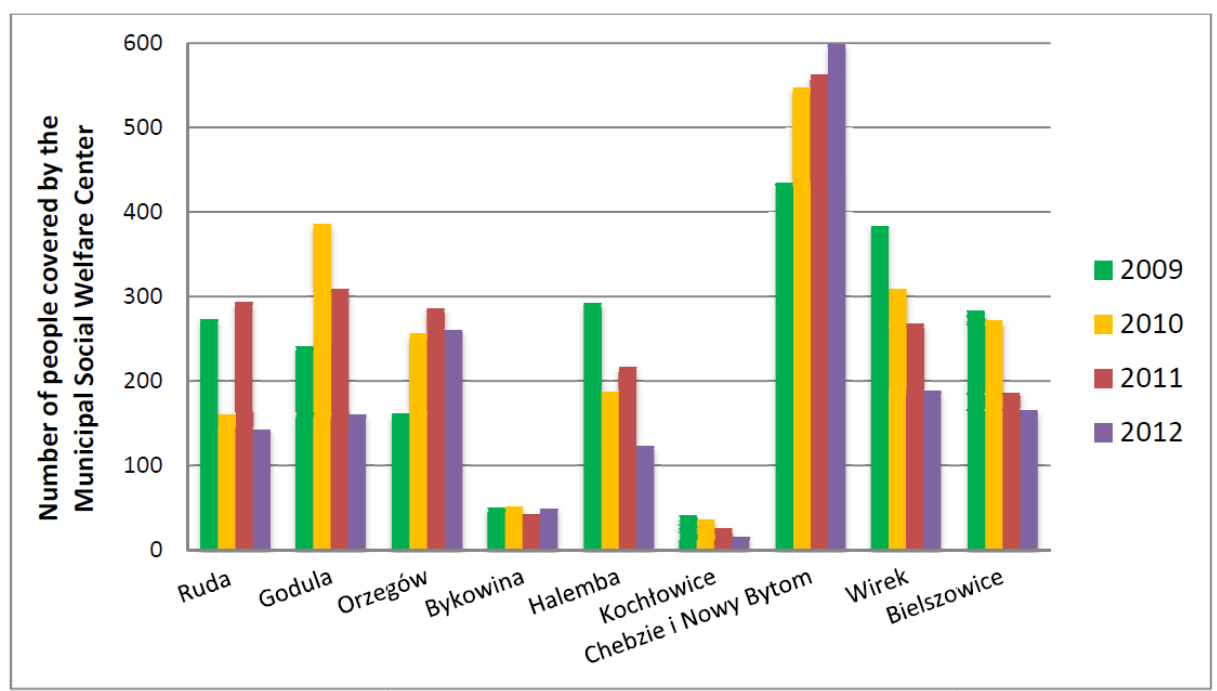

Fig. 5. Number of persons covered by the Social Welfare Centre (MOPS) for helplessness in matters of parental care and household maintenance in different districts of Ruda Śląska (own study, by www.mops.rsl.pl/monitor.html)

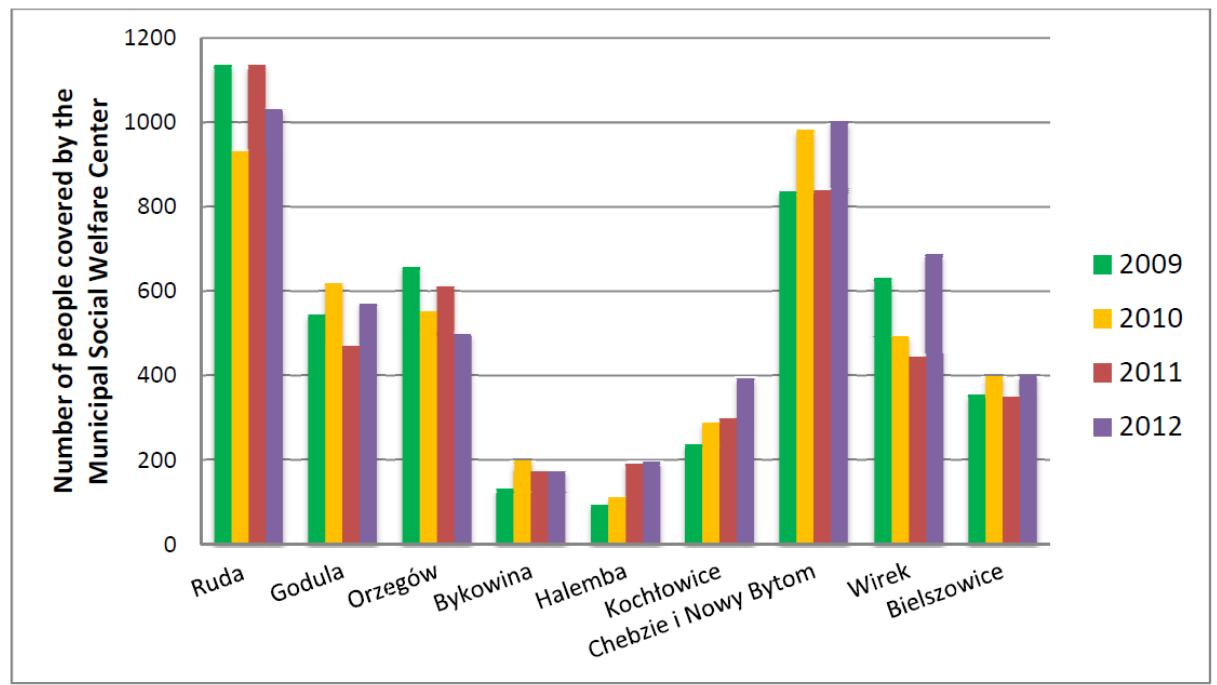

Fig. 6. Number of persons covered by the Social Welfare Centre (MOPS) for poverty in different districts of Ruda Śląska (own study, by www.mops.rsl.pl/monitor.html)

Municipal Social Welfare Centres play an important role in the social welfare system. 10 stationary outlets of social assistance and 4 childcare centers operate within the city. In addition, there are 11 day care centers (overall) taking care of children and young people (as of 31.12.2011, www.stat.gov.pl). Therefore, Ruda Śląska has the largest number of centers of this type, and the most advantageous conversion of place in welfare centers per number of inhabitants in the Upper Silesian Metropolitan Union. In 2012, the family benefits were availed by 2118 families who received family allowances for children. 8749 people benefited from environmental welfare (ie. 3787 households). Activity of Centres for Social Welfare is favorably evaluated both by the residents and the regional authorities. In 1998, the then Municipal Social Assistance Program was awarded by Local Katowice
Voivodeship Government. The share of expenditure on social assistance income city budget was $22.15 \%$ in 2005 , and $19.8 \%$ in 2012.

\subsection{Housing resources}

Other elements consisting of the entirety of socio-economic effects are changes in the housing economy. The ownership structure of the dwellings in the town is dominated by housing co-operatives of $55 \%$. The second place is occupied by individuals of $24 \%$. Subsequent positions belong to municipal premises $(15 \%)$ and establishment plants $5 \%$ (PROGRAM GOSPODAROWANIA, 2012). In 2010 there were 56953 dwellings in Ruda Śląska, 9290 of which were municipal apartments and 3035 were apartments owned by factories. In 2012 there were 543 social housing noted in the city (as for 31.12.2012, www.stat.gov.pl). To accurately assess 
the housing stock of the city should be established among others: average usable area one apartment $\left(54.8 \mathrm{~m}^{2}\right)$, average usable area per one person $\left(22.0 \mathrm{~m}^{2}\right)$ and connection for installation (waterworks 100\%, bathroom 91.7\%, central heating $77.0 \%$ ). One housing area was $54.3 \mathrm{~m}^{2}$, wherein $22.0 \mathrm{~m}^{2}$ fell to one person. The average number of rooms in a dwelling is 3.16 . In 1995 there were 56882 flats noted in the city. Back then the average area of one apartment was $50.6 \mathrm{~m}^{2}$, and usable area per one person was $17.8 \mathrm{~m}^{2}$ (ROCZNIK STATYSTYCZNY, 1995). As seen above, both the number of units and their average usable area increased. The average floor area per one person also increased. This is probably related mainly to the decreasing population density in the city.

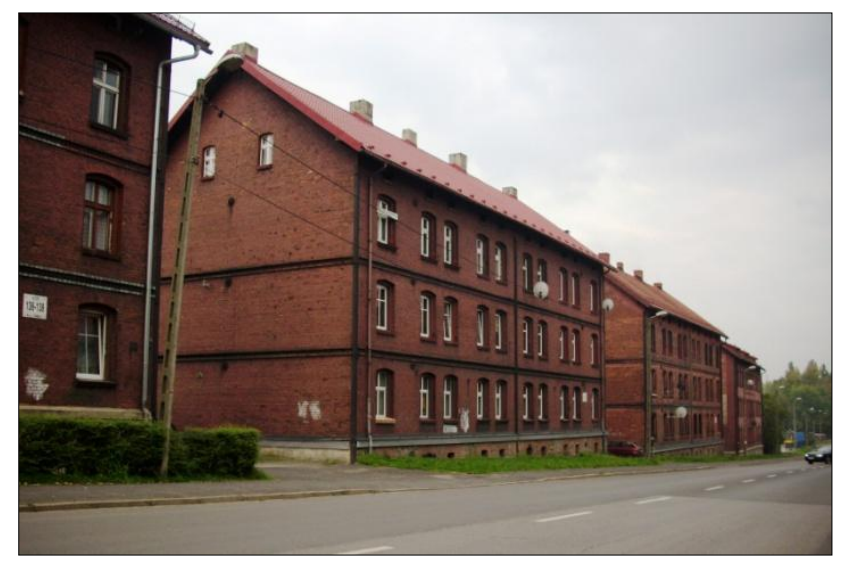

Fig. 7. Tenement houses in the Kochłowice district (K. Mazurek)

\section{Discussion of results}

The primary sector of the economy, employing a large part of Ruda Śląska residents, was and still is the industry. Working in a coal mine or steel mill enabled maintaining the whole family and the privilege of extensive package of social and household usage. Restructuring and departure from the industry has huge consequences for the functioning of the entire administrative unit (KWIATKOWSKI \& KUBIAK, 1998). As a result of mines liquidations and reducing employment in the labor market, a large group of unemployed appeared (ZDROJEWSKI, 2005). Some employees could count on benefits in the form of early retirement or payments due to the resignation from work. Tranches paid to the miners, although seemingly high, were not able to give them a decent life and facilitate re-start in the labor market (SZCZEPAŃSKI ET AL., 1999). Released workforce had to pull themselves together in a new reality. The population has found employment largely with the service sector. There were significant changes in the
The most densely built-up district is Bykowina (apartment blocks), while the least buildings are in Chebzie district (these are industrial and postindustrial areas). There are numerous residential panel blocks in Ruda Śląska located near large industrial plants and mines, buildings in older neighborhoods (Fig. 7) and family houses. Currently the trend of development of the settlement and housing has changed. Population selects locations away from the city center, adjacent to green areas, undeveloped. The most popular are detached houses, family houses and twin houses. A trend of formation of building characteristic suburban areas is visible. "Gated community" guarded settlements are created more and more often (Fig. 8).

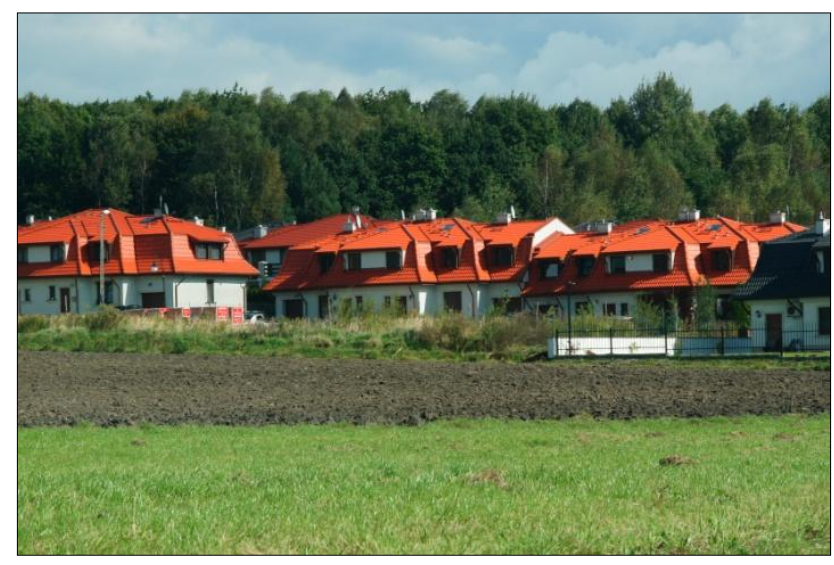

Fig. 8. Detached housing development in Ruda Śląska (K. Mazurek)

percentage distribution of employment in the three sectors of the economy (RUNGE \& RUNGE, 2006). Another consequence is an abridgment of social support provided to employees from the still active industrial workplaces. Bad economic situation did not encourage people to make decisions about starting a family, that is why there is a significant loss due to a small number of natural births in the city. In addition the population is aging which is clearly visible in the age structure and sex ratio among the population, and in the demographic ratio. Migration decisions are often made by Ruda Śląska residents, dominated by migration outside the country motivated by economic issue. A similar trend is visible in almost all traditional mining regions of central and eastern Europe (RECHŁOWICZ \& TKOCZ, 2012).

It should be noted, however, that the city is committed to providing good care for its residents. The level of expenditure attributable to the city budget per capita is the highest ( 3628 PLN in 2012) among the cities of Katowice conurbation (ex aequo with Katowice), as well as spending on 
social assistance and other tasks in the field of social policy increases. Currently, nearly $20 \%$ of the city budget is donated to the social assistance. Unemployed are offered courses and re-activation in the labor market. The city has the largest number of urban centers and childcare centers in the region. Ruda Śląska is characterized by a low percentage of overdue payments for housing, with simultaneously high average debt attributable per one tenant (2401 PLN per person). This value exceeds the average debt of residents of Katowice, Chorzow and Bytom, among others (RUNGE \& RUNGE, 2006).

The conversion of patients per one doctor is quite good, and conversion of patients per one dentist is very good. The city has only two hospitals operating within the National Health Fund and a number of smaller clinics (including operating factory clinics). The phenomenon of lengthening the average life expectancy of people is also noted. Level of deaths from injury and external causes in Ruda Śląska is higher than in the rest of Silesian province. The main causes of death city residents refer to the general trend which appears to be in the region of Silesia (ie. cardiovascular diseases and cancers).

There are visible changes in the housing economy, which set primarily for family houses and giarded estates built away from heavily urbanized areas. Families choose quiet and safe for children locations. The city adapts to changes which were presented. Along with the progressive transformation it leaves its strictly mining nature and seeks to meet current demands and trends. According to HARAŃCZYK \& SKOWRON (2010), Ruda Śląska belongs to the second group in terms of development of mining communities in Silesia voivodeship. Location in the central part of the Katowice conurbation and neighborhood of the Katowice Special Economic Zone are in the city's favor, among others, of having a strong position.

Undoubtedly, the main occupation of the population, which in Ruda Śląska is coal mining, has a great influence on the characteristics of the individual settlement. The effects of industry restructuring still occur. For this reason, it is important to continuously monitor the economic and social situation prevailing in the city. Current and systematically collected data will allow for a precise analysis of the changes in Ruda Śląska.

\section{Summary}

The restructuring of industry caused transformations not only in the structure of employment. It influenced all aspects of life in
Ruda Śląska. The article approached the effects of restructuring on the flagship example, the mining city. Despite the significant reconstruction in the employment structure, Ruda Śląska retains partly its mining character. Population of industrial and mining towns is trying to cope with the need to adapt to new economic realities, among others, by changing the sector of economy to work in. Employment reductions have contributed to the increase of population migration. In conjunction with the natural loss it resulted in a decrease of the number of population and population aging. The support of the cities and sanitary facilities offered, among others, by social assistance centers and employment has great importance in overcoming the negative effects of the economic transformation. Industry restructuring was imposed, and was put into effect which contributed to the reconstruction of the existing structure of employment. Administrative units, such as mining municipals, along with the communities living in them, are trying to facilitate the re-activation of the labor market and provide decent social support.

\section{References}

Część ogólna miejskiej strategii rozwiązywania problemów społecznych na lata 2003-2015. Urząd Miasta Ruda Śląska, 2004.

Dworak J. S. 1970. Najstarsze wiadomości z dziejów miasta. [in:] Szefer A. (ed.) Ruda Śląska. Zarys rozwoju miasta. Wyd. Śląsk. Katowice: 33-43.

Górnictwo węgla kamiennego, polityka państwa i sektora na lata 1996-2000. Program rządowy, 1996.

Harańczyk A., Skowron E. 2010. Zróżnicowanie poziomu rozwoju gmin górniczych województwa śląskiego. Zesz. nauk. Uniw. Ekonom. w Krakowie, 821. UE, Kraków: 47-60.

Jaros J. 1970. Dzieje miasta do 1922 roku. W okresie uprzemysłowienia. [in:] Szefer A. (ed.) Ruda Śląska. Zarys rozwoju miasta. Wyd. Śląsk, Katowice: 44-64.

Kondracki J. 2002. Geografia regionalna Polski. Wyd. Nauk. PWN, Warszawa.

Kwiatkowski E., Kubiak P. 1998. Poziom rozwoju gospodarczego i dynamika restrukturyzacji a bezrobocie regionalne w Polsce. Gospodarka Narodowa, 7: 27-41.

Lokalna strategia zatrudnienia i promocji przedsiębiorczości w Rudzie Ślq̨skiej na lata 2008-2015. Urząd Miasta Ruda Śląska, 2008.

Luksa J. 1959. Rozwój wydobycia w kopalniach węgla kamiennego w Polsce $w$ latach 1769-1948. Studia i Mat. Pol. Tow. Ekonom., Katowice: 3-70.

Magda-Żabińska K. 2008. Bariery ograniczające rozwój miasta Ruda Śląska. Kształt. środ. geogr. i ochr. przyr. na obsz. uprzem. i zurban., 39: 58-67.

Mazurek K. (in print). Rozwój górnictwa węgla kamiennego w Rudzie Śląskiej od XVIII wieku do czasów współczesnych. Z badań nad wpływem antropopresji na środ., 15: 71-79.

Plan rozwoju lokalnego miasta Ruda Śląska na lata 20042013. Urząd Miasta Ruda Śląska, 2004.

Program gospodarowania mieszkaniowym zasobem miasta Ruda Śląska w latach 2012-2016. Urząd Miasta Ruda Śląska, 2012. 
Program likwidacji zdolności produkcyjnych górnictwa węgla kamiennego w latach 1998-2002. Program rządowy, 1999.

Rechłowicz M., Tkocz M. 2012. Wyludnianie tradycyjnych regionów górniczych Europy środkowo-wschodniej. Studia Demograficzne, 2(162): 29-53.

Reforma górnictwa węgla kamiennego $w$ Polsce $w$ latach 1998-2002. Program rządowy, 1998.

Restrukturyzacja górnictwa węgla kamiennego $w$ latach 2004-2006 oraz strategia na lata 2007-2010. Program rządowy, 2004.

Restrukturyzacja górnictwa węgla kamiennego w Polsce. Program rządowy, 1993.

Rocznik statystyczny województwa katowickiego. Gł. Urząd Statyst., Warszawa, 1995.

Runge A., Runge J. 2006. Wybrane problemy społeczne w miastach województwa śląskiego. [in:] Słodczyk J., Szafranek E. (eds.) Kierunki przekształceń struktury gospodarczej i społeczno-demograficznej miast. Uniw. Opolski, Opole: 509-521.

Szczegółowa mapa geologiczna Polski 1:50 000, ark. Zabrze, Państ. Inst. Geol., Warszawa, 1960.
Szczepański M., Tomeczek A., Tyrybon M. 1999. Losy zawodowe pracowników kopalń odchodzących z pracy z wykorzystaniem jednorazowych odpraw pieniężnych bezwarunkowych. Próba analizy socjologicznej. Wiad. Górnicze, 1: 9-16.

Tkocz M. 2006a. Efekty restrukturyzacji górnictwa węgla kamiennego w Polsce. Prace Kom. Geogr. Przemysłu, 9: 28-39.

Tkocz M. 2006b. Przemiany funkcjonalne miast konurbacji katowickiej w latach 1989-2003. [in:] Słodczyk J., Szafranek E. (eds.), Kierunki przekształceń struktury gospodarczej $i$ społeczno-demograficznej miast. Uniw. Opolski, Opole: 71-84.

Zdrojewski E. Z. 2005. Regiony o najwyższej stopie bezrobocia. Wiadomości Statystyczne, 5: 42-54.

http://gornictwo.wnp.pl/kopalnie/

www.khw.pl/

www.kwsa.pl/

www.mops.rsl.pl/monitor.html

www.stat.gov.pl 